\title{
a força do hábito
}

O hábito torna belo o erro.

Christian Fürchtegott Gellert

I

Gente comum comumente não se importa

com gente comum.

E vice-versa.

Gente comum acha fora do comum

que a achem fora do comum.

É que já não é gente comum.

E vice-versa.

II

Que a tudo a gente se habitue,

a isso a gente se habitua.

É o que habitualmente se chama

um processo de aprendizagem.

III

É doloroso,

quando a dor de hábito não vem.

Como se cansa a mente esperta

Da própria esperteza!

O cara simples aí acha difícil por exemplo

ser um cara simples,

ao passo que aquela personalidade complexa

desfia suas dificuldades

como a beata o rosário.

Por toda parte esses eternos principiantes,

em estado terminal faz tempo.

Mesmo o ódio é um hábito do peito. 
IV

Estamos habituados

ao que não tem precedentes.

Temos o usucapião

do que não tem precedentes.

Um escravo de seus hábitos

topa na esquina de hábito

com um criminoso habitual.

Uma ocorrência inaudita.

A merda de hábito.

Os clássicos pegaram o hábito

de romanceá-la.

V

Suavemente o hábito da força repousa

na força do hábito. 